\title{
Errata: Twenty-first century global anthropogenic warming convective model
}

\section{Neale R. Neelameggham}

Brian R. Davis

Errors appeared in this paper when it was published in Nanomaterials and Energy 4(2): 143-152, http://dx.doi.org/10.1680/jnaen.15.00014.

On page 147, in line 24 of the right-hand column, the temperature should read $0.66^{\circ} \mathrm{C}$, not $0.066^{\circ} \mathrm{C}$.
On page 150, in the final line of the left-hand column, the text should read $10.6 \times 10^{20} \mathrm{~J}$, not $10.6 \times 1020 \mathrm{~J}$. 